\title{
Towards a sustainable approach to wastewater treatment strategy for eutrophication abatement
}

\author{
Elena Neverova-Dziopak ${ }^{1, *}$ \\ ${ }^{1}$ AGH University of Science and Technology, Faculty of Surveying and Environmental Engineering, \\ Department of Environmental Mangement and Protection. Al. Mickiewicza 30, 30-059 Kraków
}

\begin{abstract}
Eutrophication is one of the consequences of the negative anthropogenic impact on aquatic ecosystems. It leads to the degradation of both sweet and marine ecosystems, constituting a kind of secondary pollution of waters, which disturbs all types of their use.

Undertakings related to preventing the negative effects of eutrophication are mainly conducted towards reducing the loads of nutrients introduced into surface waters and controlling the entire conditions in aquatic ecosystems in order to limit the development of aquatic vegetation.

The increasingly restrictive legal requirement regarding the content of nitrogen and phosphorus in wastewater discharged into recipients enforces the application of expensive treatment technologies, and the public is becoming more aware of the rising costs of water and wastewater fees. In addition, wastewater treatment is a factor which has a negative impact on air quality due to greenhouse gas emissions and generates other environmental problems. The challenge for facilities, however, is determining which treatment alternatives will best meet their needs, both technically and financially, and to choose the most sustainable path.

The problem of establishing a reasonable level of nutrient removal from wastewater, justified from an ecological and economic point of view is discussed in the paper.
\end{abstract}

\section{Topicality of the problem}

Anthropogenic eutrophication is one of the consequences of negative anthropogenic impact on aquatic ecosystems. Already, at the end of the twentieth century, this problem was considered to be very current, and now it is a priority problem on a global scale. Eutrophication leads to the degradation of both freshwater and marine ecosystems, constituting a kind of secondary pollution of waters, which disturbs all types of their use. According to the Survey of the State of the World's Lakes, currently eutrophication is the main cause of the deterioration of water quality in 54\% of the lakes in Asia, 53\% in Europe, $48 \%$ in North America, $41 \%$ in South America and 28\% - in Africa [1]. According to the European Environment Agency, the risk of exposure to eutrophication for the EEA member countries and those cooperating with the EEA is very high, as illustrated in Fig. 1. The

\footnotetext{
*Corresponding author: elenad@agh.edu.p1
} 
consequences of the eutrophication process as a kind of secondary water pollution are very dangerous in terms or ecology and human health.

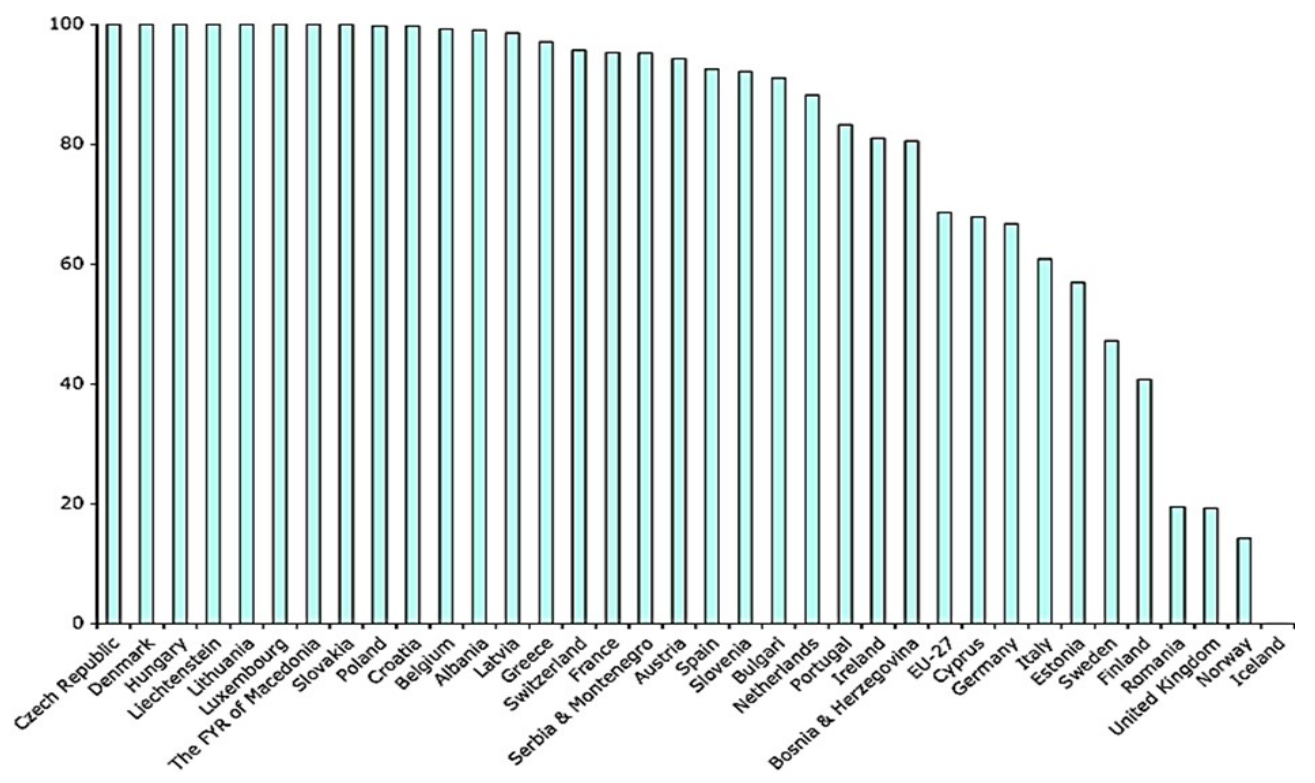

Fig. 1. Percentage of ecosystem area at risk of eutrophication for EEA Member Countries and EEA Cooperating Countries in 2010 for a current legislation (CLE) scenario [2].

All the consequences of eutrophication are associated with enormous economic losses. For example, the annual economic losses due to eutrophication in the countries of the Baltic Sea catchment region amounted to 3.76-4.38 billion euros. The unit economic losses due to eutrophication in individual countries are presented in Figure 2. Value estimates are in purchasing power parity adjusted 2015 euros [3].

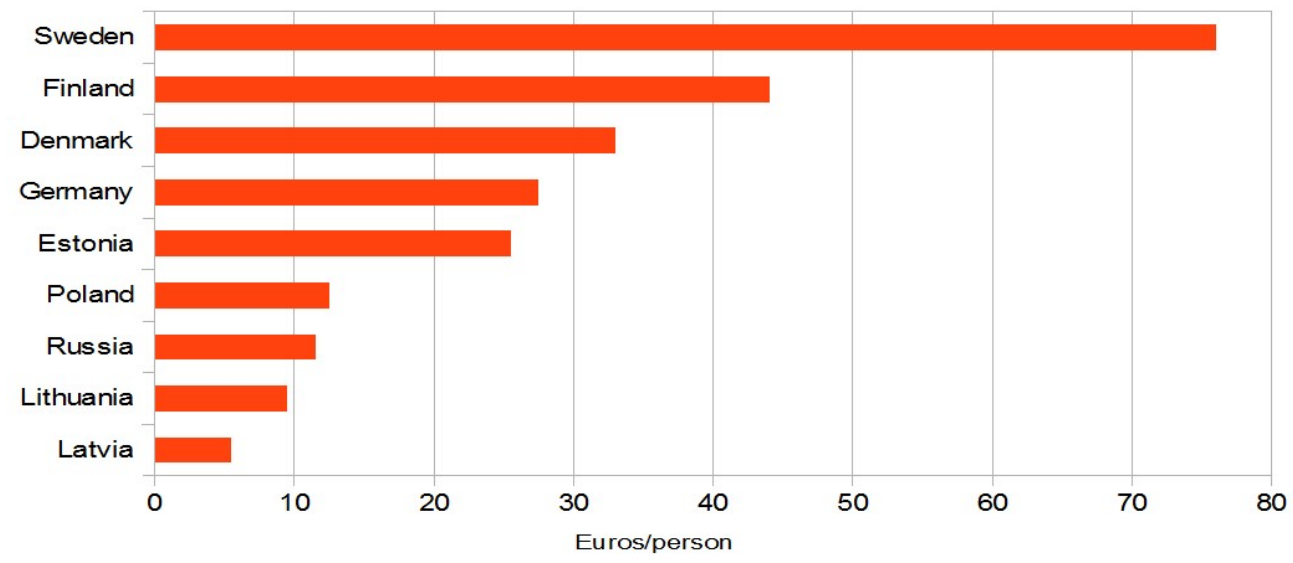

Fig. 2. Annual benefit losses from eutrophication (euros per person) (on the base of [3]).

\section{The main causes and sources of eutrophication}

The reason for the intensification of eutrophication processes development is the excessive discharge of anthropogenic loads of nutrients into surface waters. The main biogenic substances, i.e. substances essential to the growth and development of aquatic vegetation, 
are the mineral forms of nitrogen and phosphorus, which are considered to be the main limiting factors in the eutrophication process. Numerous literature reports from different regions of the world indicate that the basic load of nitrogen to surface waters is supplied from dispersed sources (agriculture, atmospheric pollution), with the dominating share of area runoff from agricultural land, which provides about $64 \%$ of the total nitrates load. On the other hand, phosphorus loads are supplied mainly from point sources, i.e. along with wastewater discharged into water receivers, and therefore the main source of phosphorus supply into surface waters are municipal wastewaters which together with industrial wastewaters are responsible for the introduction of approx. $88 \%$ of total phosphate load into receivers [4-10]. In turn, the share of area and point sources of biogenic pollution in selected water bodies in Europe is illustrated in Table 1.

Undertakings related to preventing the negative effects of eutrophication are mainly conducted towards reducing the loads of nutrients discharging into surface waters, and controlling the totality of biotic and abiotic conditions in aquatic ecosystems in order to limit the intensity of the development of aquatic vegetation, which is carried out within their reclamation and restoration.

Table 1. The share of point and area sources of biogenic pollution [11].

\begin{tabular}{|c|c|c|c|c|c|c|c|c|}
\hline & \multicolumn{4}{|c|}{ Nitrogen } & \multicolumn{4}{|c|}{ Phosphorus } \\
\hline Catchment & 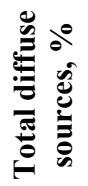 & 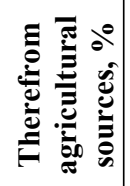 & 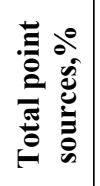 & 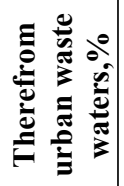 & 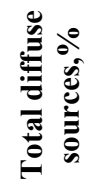 & 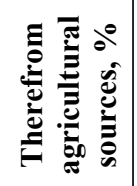 & 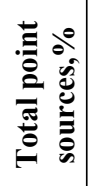 & 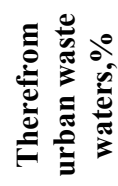 \\
\hline North Sea & 69 & 85 & 31 & 89 & 44 & 85 & 56 & 77 \\
\hline Baltic Sea & 45 & $70-90^{*}$ & 12 & 90 & 45 & $60-80 *$ & 20 & 90 \\
\hline $\begin{array}{c}\text { Po River } \\
\text { basin }\end{array}$ & 80 & - & 20 & 57 & 93 & - & 7 & 90 \\
\hline $\begin{array}{c}\text { Ebro river } \\
\text { basin }\end{array}$ & 64 & - & - & - & - & - & 88 & - \\
\hline $\begin{array}{c}\text { Rhine River } \\
\text { basin }\end{array}$ & 69 & - & 31 & $84 * *$ & 51 & - & 49 & 89 \\
\hline $\begin{array}{c}\text { Danube } \\
\text { River basin }\end{array}$ & 84 & 42 & 16 & 25 & 67 & 28 & 33 & 51 \\
\hline $\begin{array}{c}\text { Lake } \\
\text { Constance }\end{array}$ & 81 & - & 19 & - & 88 & - & 12 & - \\
\hline
\end{tabular}

Note: Not included in this table are natural background loadings and unspecified loads

*agricultural contribution to total riverine load

** diffuse urban loads included

\section{Economic aspects of nutrients removal}

Particular attention is currently being paid to the removal of nitrogen and phosphorus compounds from wastewater is a reflection of their increasing role in the intensification of surface eutrophication processes in many countries, related to economic development and urbanization. The removal of nutrients from wastewater has become a current problem when it has been found that conventional treatment methods are ineffective in removing nitrogen and phosphorus. In recent decades, advanced wastewater treatment technologies have been introduced in many countries to increase nutrient removal. The requirements regarding the quality of municipal wastewaters discharged from wastewater treatment 
plants into the aquatic environment in the EU countries are established by the Directive 91/271/EEC concerning urban waste-water treatment [12].

The increasingly restrictive requirements regarding the content of nutrient compounds in wastewaters demand the use of expensive advanced treatment technologies, and the public is becoming more aware of the rising costs of water and wastewater fees.

The advanced nitrogen and phosphorus removal from municipal wastewater may be achieved by various currently available biological, chemical and physical treatment processes. Enhanced biological treatment allows achieving TN effluent concentrations as low as $3 \mathrm{mg} / \mathrm{l}$ [13]. Biological, chemical, and physical processes may be combined to achieve very low TP concentrations, up to $0,01 \mathrm{mg} / 1$ [14].

The advanced nutrients removal technologies are very expensive and overstrain local and national state budgets. In addition, wastewater treatment plants are a factor with a negative impact on air quality due to, among other things, greenhouse gas emissions and generate other environmental problems that intensify with the use of more advanced equipment and processes. Thus, the problem of establishing a reasonable level of nutrient removal from wastewater, justified from an ecological and economic point of view is a very important issue and currently being discussed in many publications.

One of the most spectacular examples of a disturbance in the optimal balance between the level of wastewater treatment, the degree of unfavourable impact of a treatment plant on the environment and the costs of nutrients removal are the results of simulation tests, which allow the assessment of the reasonable level of nutrient removal from wastewater [15]. In this study the impact of different levels of nutrients removal from wastewater discharged into the water receiver on a potential increase in algae production (as eutrophication indicator) and associated greenhouse gas emissions into the atmosphere was investigated. Within this study, the impact of wastewater treated using 5 different technologies with a different efficiency of nutrient elimination was analysed: from methods without biogenic matter removal to treatment using the reverse osmosis process. The assumptions of the simulation tests are presented in Table 2 .

Table 2. The assumptions of simulation (on the base of [15]).

\begin{tabular}{|c|c|c|c|}
\hline Treatment level & Technology & $\begin{array}{c}\text { TP in treated } \\
\text { wastewater, mg/l }\end{array}$ & $\begin{array}{c}\text { TN in treated } \\
\text { wastewater, mg/l }\end{array}$ \\
\hline Level 1 & $\begin{array}{c}\text { Secondary Treatment } \\
\text { (No nutrient removal) }\end{array}$ & No removal & No removal \\
\hline Level 2 & $\begin{array}{c}\text { Biological Nutrient } \\
\text { Removal (BNR) }\end{array}$ & 1,0 & 8,0 \\
\hline Level 3 & $\begin{array}{c}\text { Enhanced Nutrient } \\
\text { Removal (ENR) }\end{array}$ & $0,1-0,3$ & $4,0-8,0$ \\
\hline Level 4 & $\begin{array}{c}\text { Limit of Treatment } \\
\text { Technology }\end{array}$ & $<0,1$ & 3,0 \\
\hline Level 5 & Reverse Osmosis (RO) & $<0,02$ & 2,0 \\
\hline
\end{tabular}

The influence of wastewater discharge treated with different technologies (with different nitrogen and phosphorus effluent content) on algae biomass growth and relevant greenhouse gas (GHG) emissions is illustrated in Figure 3. 


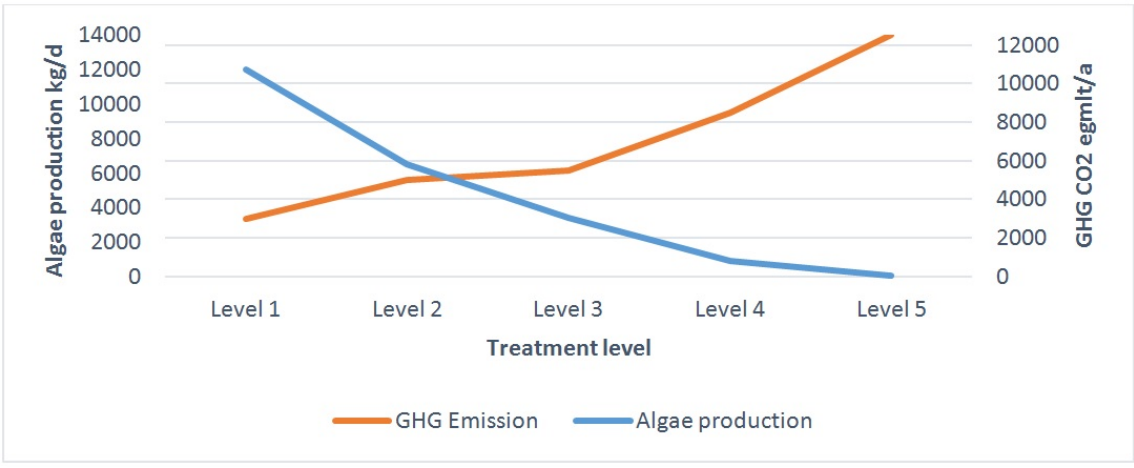

Fig. 3. The influence of treated wastewater discharge on algae production and appropriate GHG emission (expressed as $\mathrm{CO}_{2}$ eq $\mathrm{mt} / \mathrm{yr}=$ metric tonnes of carbon dioxide equivalents per year) (on the base of [15]).

An analysis of the results of the above simulation allowed formulating the following conclusions:

- the reduction of algae biomass production as an indicator of eutrophication process intensity to $95 \%$ can be achieved by wastewater treatment in advanced nutrient removal technologies (ENR), which allow obtaining the following levels of nitrogen and phosphorus content: TP 0.1-0.3 mg/l and TN 4-8 mg/l;

- in the technologies of Level 4 and Level 5 the remaining 4\% content of biogenic compounds can be removed, but at the same time the greenhouse gas emissions are also doubled;

- in comparison with the technologies of Level 1, the cost of wastewater treatment is increased by one third with the use of conventional biological treatment technology and five times - using reverse osmosis [15].

Another example is the simulation research provided by Jiang et al. [16] presenting the calculations of the costs of increasing the total phosphorus reduction rate under the modernization of a biological treatment plant with simultaneous phosphorus precipitation with the help of $\mathrm{Al}_{2}\left(\mathrm{SO}_{4}\right)_{3}$ (Table 3). In the calculation of the unit removal costs of $1 \mathrm{~kg} \mathrm{P}$ for various configurations of the technological scheme and different plant capacity, the expenditures on energy, labour, chemical reagents, sludge utilization, operation and maintenance costs were taken into account.

The analysis of data from table 6 allows the conclusion that under increasing the level of total phosphorus reduction in wastewater in different scenarios of biological treatment from $2.0 \mathrm{mg} / 1$ to $0.13 \mathrm{mg} / \mathrm{l}$ leads to an increase in the unit cost of phosphorus removal dozens of times. According to the authors of the research, under TP effluent limits of 0.05 to $2.0 \mathrm{mg} / \mathrm{L}$, the technology based on an activated sludge reactor enhanced by the addition of $\mathrm{Al}_{2}(\mathrm{SO} 4)_{3}(\mathrm{AS}+$ alum scenario) was the most economical, perhaps demonstrating that the unit costs of phosphorus removal are lower in plants with chemical precipitation due mainly to the higher capital costs of installing the anaerobic tank volume necessary for upgrading the biological processes of phosphorus removal (Fig. 4). 
Table 3. Detailed estimated costs for different scenarios of total phosphorus removal [16].

\begin{tabular}{|c|c|c|c|c|c|c|}
\hline \multirow{2}{*}{$\begin{array}{c}\text { Total phosphorus in treated } \\
\text { wastewater (achieved in 3 different } \\
\text { technological scenarios for each } \\
\text { level of removal) }\end{array}$} & \multicolumn{5}{|c|}{ Unit cost (\$/kg TP.) } \\
\cline { 3 - 7 } & & $\mathbf{3 7 8 5}$ & $\mathbf{3 7 8 5 0}$ & $\mathbf{7 5 7 0 0}$ & $\mathbf{1 8 9 2 5 0}$ & $\mathbf{3 7 8 5 0 0}$ \\
\cline { 3 - 7 } 2,0 & $\mathrm{AS}+\mathrm{Al}$ * & 30,8 & 10,2 & 8,98 & 8,20 & 7,91 \\
$\mathrm{2} g / 1$ & $\mathrm{~A} / \mathrm{O}$ & 61,2 & 27,2 & 23,4 & 20,0 & 18,7 \\
& $\mathrm{~A} / \mathrm{A} / \mathrm{O}$ & 72,6 & 29,0 & 24,5 & 20,6 & 19,5 \\
\hline \multirow{2}{*}{1,0} & $\mathrm{AS}+\mathrm{Al}$ & 28,4 & 14,9 & 14,1 & 13,5 & 13,3 \\
$\mathrm{mg} / 1$ & $\mathrm{~A} / \mathrm{O}+\mathrm{Al}$ & 68,0 & 35,4 & 31,5 & 28,3 & 26,9 \\
& $\mathrm{~A} / \mathrm{A} / \mathrm{O}+\mathrm{Al}$ & 87,0 & 37,7 & 32,9 & 29,1 & 27,6 \\
\hline \multirow{2}{*}{0,5} & $\mathrm{AS}+\mathrm{Al}+\mathrm{F}$ & 195,0 & 71,6 & 61,4 & 55,8 & 54,5 \\
$\mathrm{mg} / 1$ & $\mathrm{~A} / \mathrm{O}+\mathrm{Al}+\mathrm{F}$ & 237,0 & 87,4 & 74,8 & 66,8 & 64,4 \\
& $\mathrm{~A} / \mathrm{A} / \mathrm{O}+\mathrm{Al}+\mathrm{F}$ & 269,0 & 89,0 & 75,8 & 67,1 & 65,1 \\
\hline \multirow{2}{*}{0,13} & $\mathrm{AS}+\mathrm{Al}+\mathrm{F}$ & 250,0 & 138,0 & 129,0 & 125,0 & 123,0 \\
$\mathrm{mg} / 1$ & $\mathrm{~A} / \mathrm{O}+\mathrm{Al}+\mathrm{F}$ & 268,0 & 130,0 & 118,0 & 111,0 & 109,0 \\
& $\mathrm{~A} / \mathrm{A} / \mathrm{O}+\mathrm{Al}+\mathrm{F}$ & 277,0 & 131,0 & 119,0 & 111,0 & 110,0 \\
\hline \multirow{2}{*}{0,05} & $\mathrm{AS}+\mathrm{Al}+\mathrm{S}+\mathrm{F}+\mathrm{UF}$ & 387,0 & 200,0 & 183,0 & 167,0 & 162,0 \\
$\mathrm{mg} / 1$ & $\mathrm{~A} / \mathrm{O}+\mathrm{S}+\mathrm{Al}+\mathrm{F}+\mathrm{UF}$ & 416,0 & 207,0 & 187,0 & 169,0 & 163,0 \\
& $\mathrm{~A} / \mathrm{A} / \mathrm{O}+\mathrm{Al}+\mathrm{S}+\mathrm{F}+\mathrm{UF}$ & 423,0 & 206,0 & 186,0 & 168,0 & 162,0 \\
\hline
\end{tabular}

$* \mathrm{AS}+\mathrm{Al}$ - activated sludge reactor + introduction of $\mathrm{Al}_{2}(\mathrm{SO} 4)_{3} ; \mathrm{A} / \mathrm{O}$ - anoxic-oxygen reactor; A / A / O - anoxic-anaerobic-oxygen reactor; F - filter; S - intermediate clarifier; UF - ultrafiltration

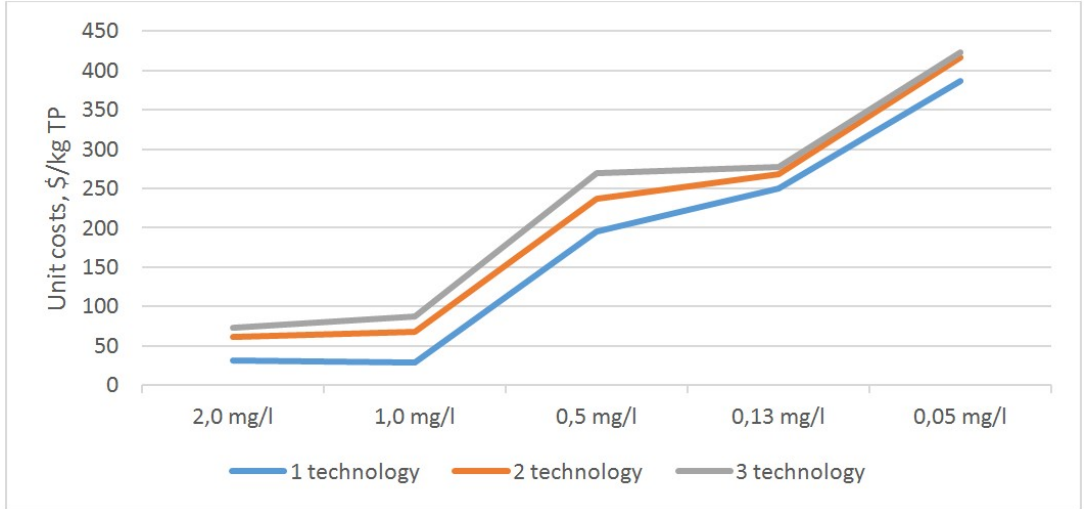

Fig. 4. The comparison of unit costs of TP removal for different level of total phosphorus reduction achieved in 3 treatment scenarios for small treatment plants of $3785 \mathrm{~m}^{3} /$ day capacity (on the basis of [16]).

\section{Conclusions}

The proper choice of waste water treatment technology is currently a very important issue in the field of wastewater management due to the enormous costs of modern technologies. In less developed countries, the construction of modern wastewater treatment plants is often financed from numerous international funds. However, both operational and maintenance costs must be covered from the budgetary resources of individual countries [17] and can significantly burden them and unbalance their structure. The challenge is determining which treatment alternatives will best meet the needs of the individual countries, both technically and financially, and to choose the most sustainable technology, also considering its reliability, sustainability and environmental considerations [18]. Actually, engineers and 
designers often see a solution to this problem in the maximum possible level of pollution reduction in discharges, which simplifies the calculation and choice of the treatment technological scheme. Currently, the most popular approach to assessing the degree of wastewater treatment is based on the BAT approach (Best Available Technology) and "end of pipe" approach (treated wastewater must meet the established standards). Such an approach, based on the possibilities of modern technologies, does not always guarantee the ecological safety of surface waters. In addition, BAT technologies are also very expensive. When the quality of treated wastewater approaches the quality of the receiver's water, the costs of their treatment increase in geometric progression, and at the same time significantly reduce their effectiveness. In practice, there is a paradoxical situation standards are more and more stringent, expenditures for wastewater treatment and penalties pollution discharge are growing, but the state of the water environment often deteriorates and leaves much to be desired.

Due to the fact that when the degree of reduction of wastewater pollution is increased, the costs of treatment increases in accordance with the exponential function; society cannot afford the almost $100 \%$ removal of pollutants from wastewater. For example, the US Environmental Protection Agency has estimated the cost of treatment of all municipal and industrial wastewaters with an 85\% reduction efficiency during the period 1971-1981 at 62 billion dollars. On the other hand, full removal of pollutants would cost 317 billion dollars, while removing $15 \%$ of the remaining pollutants would cost 5 times more than removing the first $85 \%$ of pollutants [19].

From the above considerations, it can be pointed out that, if the costs of wastewater treatment are very high, it can exceed the economic benefits of pollutants removal, which may lead to local and regional budgets being overloaded and to the bankruptcy of many industrial plants. In this case, the principle of sustainable development will be violated. Therefore, it is very important to determine the optimal levels of removal of pollutants from wastewater based on a cost-benefit analysis of protective investments.

\section{References}

1. Managing Lakes and their Basins for Sustainable use. A Report for Lake and their Basins for Sustainable Use. A Report for Lake Basin Managers and Stakeholders. International Lake Environment Committee Foundation (ILEC) (2005)

2. Exposure of ecosystems to acidification, eutrophication and ozone. European Environment Agency. Available at: [https://www.eea.europa.eu]

3. H. Ahtiainen, J. Artell, M. Czajkowski, B. Hasler, L. Hasselström, A. Huhtala, J. Meyerhoff, J.C.R. Smart, T. Söderqvist, M.H. Alemu, D. Angeli, K. Dahlbo, V. Fleming-Lehtinen, K. Hyytiäinen, A. Karlõševa, Y. Khaleeva, M. Maar, L. Martinsen, T. Nõmmann, K. Pakalniete, I. Oskolokaite \& D. Semeniene, Journal of Environmental Economics and Policy 3 (3), 278-305 (2014)

4. N.J.Torrecilla, J.P. Galve, L.G. Zaera, J.F. Retamar, A.N. A, Journal of Hydrology 304, 166-182 (2005)

5. Limnologischer Zustand des Bodensees, Bericht. International Commission for the Protection of Lake Constance IGKB,40 (2014). Available at: (http://www.igkb.org/fileadmin/user_upload/dokumente/publikationen/gruene_berichte 140_gb40_ges amtbericht.pdf) accessed 05 August 2016

6. N. Pirrone, G. Trombino, E. Pesenti, P. Palopoli. General Description of the Po River Catchment and the Norther Adriatic Basin. POCAT Report prepared under the EUfunded EUROCAT project (2002) 
7. Das Phytoplankton des Rheins 2012‘, International Commission for the Protection of the Rhine, Koblenz. ICPR, (2015). Available at: (http://www.iksr.org/fileadmin/user_upload/Fachberichte/fb_224_de.pdf) accessed 05 August 2016;

8. Eutrophication in the Baltic Sea - an Integrated Thematic Assessment of the Effects of Nutrient Enrichment in the Baltic Sea Region', in: Baltic Sea Environment Proceedings No. 115B, HELCOM, Helsinki, Finland, (2009) (http://www.helcom.fi/Lists/Publications/BSEP115b.pdf accessed 05 August 2016].

9. M. Henze. Wastewater Treatment: Biological and Chemical Processes. Berlin: Springer-Verlag, (1995)

10. E.S. Gogina. Udalenie biogennych elementów iz stocznych wod. MISI, Moskwa (2010)

11. European Assessment of Eutrophication Abatement Measures across Land-based Sources, Inland, Coastal and Marine Waters, ETC/ICM Technical Report 2 (2016)

12. Council Directive 91/271/EEC of 21 May 1991 concerning urban waste-water treatment

13. T. Freed. Wastewater Industry Moving Toward Enhanced Nutrient Removal Standards. Water World, March (2007). Available at:http://ww.pennnet.com/articles/article_display.cfm?article_id=286210].

14. M. Suplee, P. Hartman, J. Cleland, Wastewater Treatment Performance And Cost Data To Support An Affordability Analysis For Water Quality Standards, Montana Department of Environmental Quality, Helena, Montana, (2007). Available at http://www.kysq.org/docs/Wastewater_2007.pdf]

15. Striking the balance between Nutrient removal in wastewater treatment and sustainability (NUTR1R06n). Executive Summary, WERF

16. F. Jiang, M.B. Beck, R.G. Cummings, K. Rowles, D. Russell, Water Policy Working Paper 011, (2005)

17. Causes and Effects of Eutrophication In the Black Sea. Summary Report, Programme Coordination Unit UNDP/GEF Assistant (1999)

18. Cost Estimates Phosphorus Removal at Wastewater Treatment Plants. Technical Support Document, Ohio Environmental Protection Agency (2013). Available at: [http://epa.ohio.gov/Portals/35/wqs/nutrient_tag/OhioTSDNutrientRemovalCostEstima te_05_06_13pd]

19. G.T. Miller. Living in the Environment. Wadsworth Publishing Company, Belmont, California, 397 p. (1996) 